\title{
高圧の細菌に及ぼす影響に就いて
}

\section{第二篇 細菌の酵素作用に及齐す高壓の影響}

\author{
指導村上栄教授 \\ 指咱 林香苗教授
}

阙山大学医学部細菌学教室

市橋大

[昭和 28 年 12 月 24 日受稿]

\section{第一草 䋛言}

既飞第一篇に於て hydrostatic pressure が チフス菌の発育並びに增殖, 運動性等諸生活 現象飞対して著明な阻害を与へる事を立証し た. 本篇に於ては細菌の生活機能と密接な関 連を有する種々の酵素作用に及ぼす高压の影 䍹に就き実験的研究を行つた。

細胞の原形質を分析すれば蛋白質，リホイ ト，多惦類のやうな高分子化合物を得るが， 生きた原形質内では之等の物質は琶白質同志 結合したり，リポプロテイド、ポリサツカロ プロティドなど更に大きい分子を作り互に種 々の程度の強さで可変的に結合していると考 へられている. 而して斯る構造のいろいろの 部分飞低分子の物質やイオンが結合或は集合 しているであるう。亦ポリペプチド嗩自身の 形も周囲の影響により恋化すると考へられ る、酥素はそう云ふ原形質の構成分の一部で ある，而して細菌の細胞内の醉素も亦例外で はない，此の醉素の作用が種々の物質やイオ ンの存否，增隇，蛋白其の他の物質との結合， 吸着, 分離などくり影響される事は既に知 られている. 而して原形質の棈造が複篗であ ればある程, 醉素の㗢きる種々の制約を受け るわけで単離抽出された䤃素の作用とは自ら 異る所以である．私は菌体内の斯る複雓な機 構の下に於ける酵素作用を観察の対象としつ 」それが高厤の影響を蒙つて如何なる変化を 示し，且それが細菌の生活機能と如何なる有 機的関連を有するかを追求せんとして若干の
実験を行つた，本篇に於ては特に細菌の呼吸 醉素, 脱水素酵素及びカタラーゼ作用に就い て検索した。

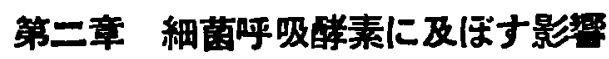

生細胞の酸素呼吸に与かる醇素にはチトク ローム及びチトクローム酸化醇素 (Warburg

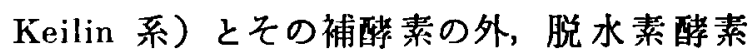
並にカタラーゼ等があるが後者は夫々単独に 研究する方法があるので後章に譲り茲では主 として生細胞の酸素呼吸江於て基質と酸素々 の最終連鎖としてその主役を演ずると考へら れるチトクローム及びチトクローム酸化酵素 の作用を観察するに最す適切な方法である Warburg の検压計を応用して細菌の酸素呼 吸が酳压の影響を如何飞蒙るかを検討し た.

\section{I 貫験方法並に基碟实驗}

供試菌，普通桿菌，球菌，芽胞菌等計 15 株 を用ひ，特定の実験を除き常に普通寒天平板 培地に $37^{\circ} \mathrm{C} 18$ 時間培養した菌を用ひ，食塩 燐酸緩衝液飞て洗淮後 resting bacteria とし て実験に供した。緩衝液の組成は $\frac{\mathrm{M}}{2} \mathrm{NaHPO}_{4}$ 8.5c.c., $\frac{\mathrm{M}}{2} \mathrm{KH}_{2} \mathrm{PO}_{4} 1.5$ c.c., $\quad 0.9 \% \mathrm{NaCl}$ 240c.c. とし， pH 7.4である.

加圧方法. 第一篇飞に於て詳述した。

酸素消費測定. Warburg の検圧計を用ひ， 対照菌と加圧菌の酸素消費量を測定した．容 器内の各容量は次に示す通りである。 


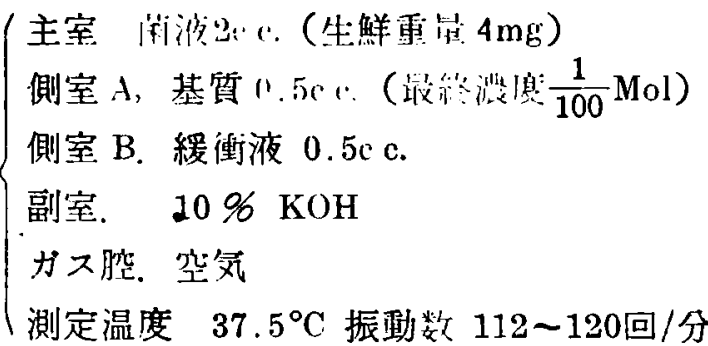

定法により恒温槽に入れて15分間振晸，温 度と気圧とが平衝を保つてから活栓を閂ぢ側 室 A，B の内容を主室内に混入した時を実験 開始時として以後 10 分或は 15 分每に酥素消 費量を目盛で読る特定の場合を除き 180 分続 けた。

基礎実験 1. 使用せる油の作用を検討する ために油を重層したるのとしないものの酸 '素消費量を比熵したが差異を認めなかつた。 実験に際しては念のため对照椒液にも同じ 油を同じ時間だけ重層して用ひた。

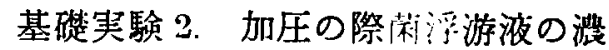
度によつて差異を生ずるか否かに就 いて棒駼を行った結果 $2 \mathrm{mg} / \mathrm{c}$.c. 攻 び $10 \mathrm{mg} /$ c.c. の濃度に於て压を加へ た後，同一橴度にして酸素消費を比 䡥した結果闭者の差は誤差範用を出 ない.

即ち hydrostatic pressure である から灌度差を考虑する要はない。 基礎実験 3. 同一実験汸於て 2 本以 上のマノメータを一つの材料に用ひ たがその平均誤差は $5 \%$ 以内江留ま つた.

\section{II－賽驗成績}

1. 高压による呼吸阻害度.

何程の圧力を加へる事によつて細菌の呼吸 阻害が見られるかといふ点に就いて惐萄糖及 びアスパラギン酸を基質として酸素消費量の 測定を行ひ，次の結果を得た。

压の高さ：加圧時間を 30 分飞一定する場 合チフス菌では $600 \mathrm{~kg} / \mathrm{cm}^{2}$ の圧迄は酸素消 費量の減少を認めないが $800 \mathrm{~kg} / \mathrm{cm}^{2}$ 飞至り 相当の娍少を認める. $1200 \mathrm{~kg} / \mathrm{cm}^{2}$ Kなると 急激なる减少を呈し， $14110 \mathrm{~kg} / \mathrm{cm}^{2}$ で殆ど酸
秦消費を示さなくなる，(第 1 図)，葡萄状球 菌ではミににし， $1600 \mathrm{~kg} / \mathrm{cm}^{2}$ 迄圧を高めて す酸素消費量の減少を示さず却つて若干の增 加を認めた。（第2図右）

\section{第1因 細菌呼吸に及ぽす消圧の影響 \\ 圧の高さとチフス菌の酸素消費量 チフス菌 $4 \mathrm{mg}$ (生解重量) 加印㭙閪 30 分}

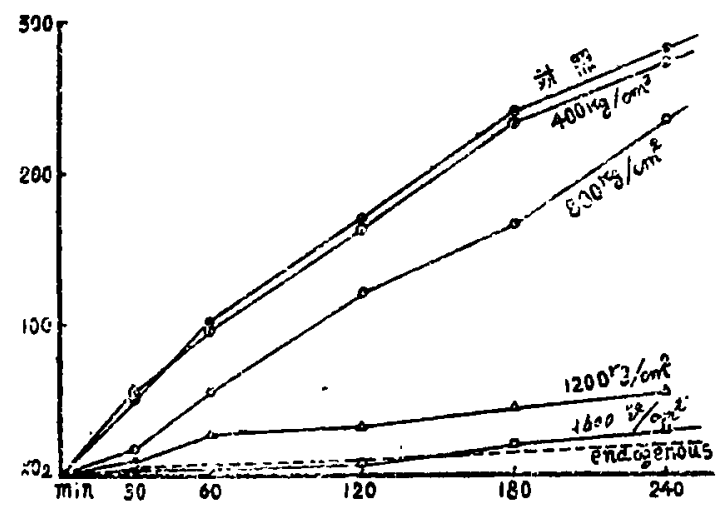

第2 因 細菌呼吸に及ぼす高圧の影短 酸素消费量の比校 加圧 $1600 \mathrm{~kg} 5^{\prime}$

A. チフス菌 $4 \mathrm{mg}$ B. 葡萄球菌 $4 \mathrm{mg}$ 基質ダルコース
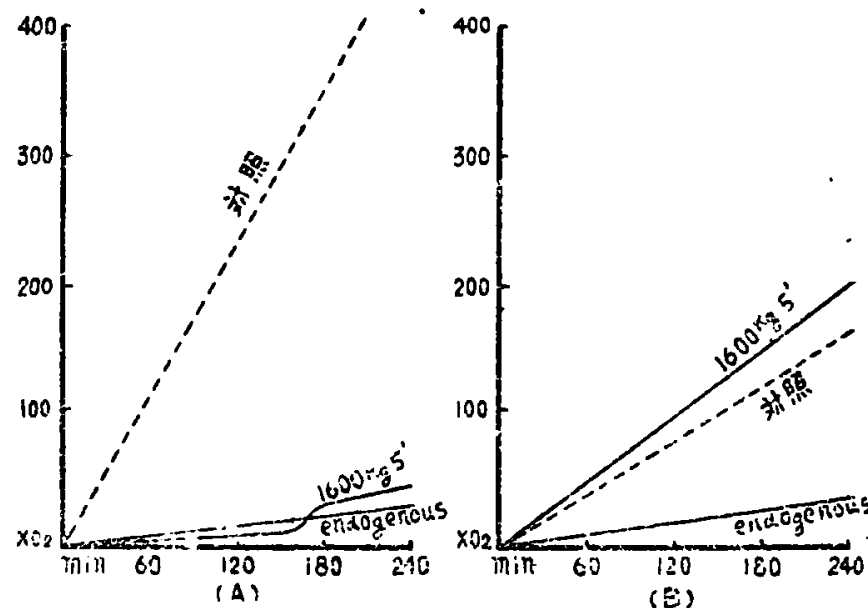

加圧時間 : チフス菌では $800 \mathrm{~kg} / \mathrm{cm}^{2}$ の圧 でも10分以内の加圧では殆ど影響を認めない. $1600 \mathrm{~kg} / \mathrm{cm}^{2}$ の圧では僅か 1 分間の 加圧飞よ つて顕著な抑制を受ける，5 分間の加圧では 除圧後初めの 2 時間は酸素の消費は零で, endogenous respiration の值より低いが振洫 後 $2 \sim 3$ 時間で次第に酸素呼吸を始め内呼吸 を超えて酸素消費量を增加するが振㯰後 6 時 間に至るる対照と同程度迄は增加しない（第 2 図左)

基質の差：同一実験に於て基質の種類例 へば苚衙糖とアスパラギン酸との間に差異を 
生ずる事は往目すべき事実である。即ち1200 $\mathrm{kg} / \mathrm{cm}^{2}$ の加圧では雨者は略同様の抑制を受 けるが $800 \mathrm{~kg} / \mathrm{cm}^{2}$ の圧では蘽萄榶の場合が 遙か火抑制度は大である（第 3 図）

第3図細菌呼吸の阻害度 対照の QO2を 100 とす 加圧 30 分間
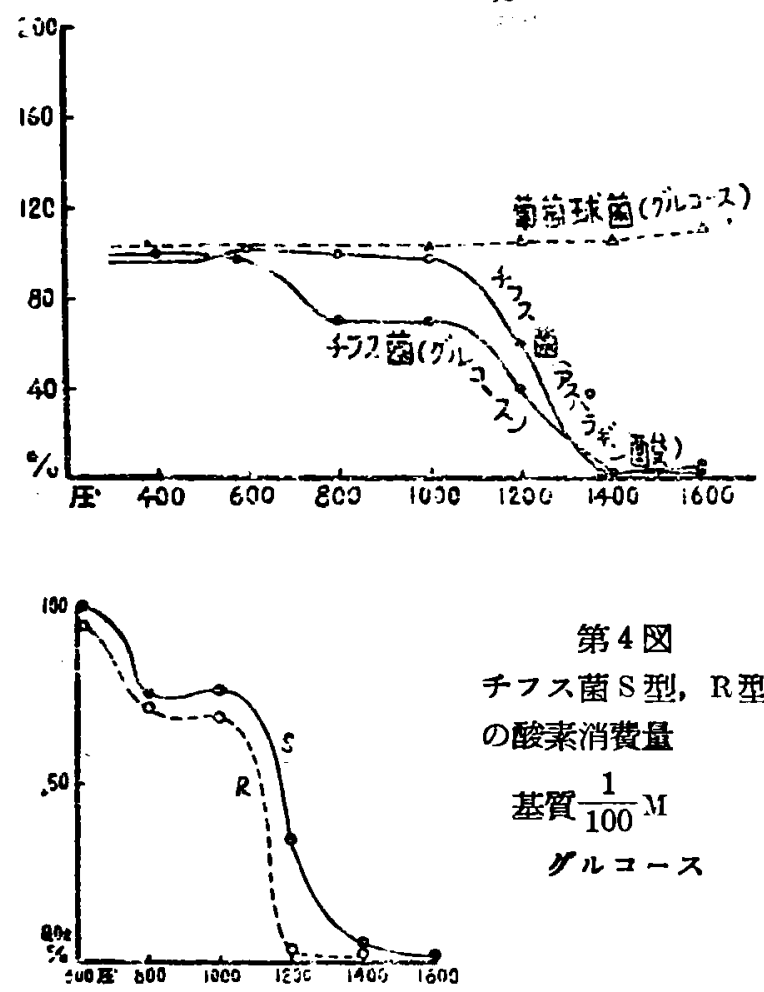

2. 菌種菌株並に莉型による差異。

細菌の菌偅，菌株並に菌型の間に高压飞対 する抗抗力の差異が有るか苔かを検する為に 第 1 表に見られる如き各種の菌を選び実験に 供した. $1600 \mathrm{~kg} / \mathrm{cm}^{2} 30$ 分の加圧によつて蒙 る呼吸の阻害度即ち酸素消費量の減少の率を 比較すれば表の如くになる，数字はQ09 $(\mathrm{cmm})$ 即ち菌 $1 \mathrm{mg}$ が 60 分間飞消費する酸 素の量を示す 之によるとチフス菌大腸菌は 阻害度最も大で $100 \%$, 次でパラチフスA菌 赤㾐菌が70〜80\%の阻害を受け，パラチフス B菌，肺炎模菌等は比較的抵抗が強い，㳦萄 状球菌と肺炎双球菌は全く抑制されず，却つ て促進される傾向を示し，馬鈴薯菌(有芽胞) は促進が著明である。菌株の間ではチフス菌 の57 株及 58 株の間に差を認めないが大腸菌 では coli communis が 100 96阻害されると対 し, coli communior は僅かに 16 96しか阻害 されない，葡萄球菌です寺島株と F, D, A 株 の間に差を認める事が出来る． $\mathrm{S}$ 型菌と $\mathrm{R}$ 型 菌の間では R 型の方が抵抗は弱く， $\mathrm{S}$ 型は $1400 \mathrm{~kg} / \mathrm{cm}^{2} 30$ 分で酸素消費が停止するが $\mathrm{R}$ 型はそれより低く $1200 \mathrm{~kg} / \mathrm{cm}^{2} 30$ 分で殆ど停 止する。（第 4 図）

第 1 表 高圧の各種䄄藻に対する呼吸阻害度

（数字は $\mathrm{Qc2}(\mathrm{cmm})$ を示す） $1600 \mathrm{~kg} / \mathrm{cm}^{2} \quad 30$ 分

\begin{tabular}{|c|c|c|c|c|c|c|c|c|}
\hline \multirow{2}{*}{\multicolumn{2}{|c|}{ 菌 }} & \multirow{2}{*}{ 種 （㧣） } & 基 犋 & \multicolumn{2}{|c|}{ Y $ル コ-\pi$} & \multicolumn{3}{|c|}{ 基政アスパラキンン酸 } \\
\hline & & & 対 照 & 被 压 & 阻害底 & 対 照 & 被 圧 & 阻害度 \\
\hline S. & typhi & & 116.0 & 0 & 10096 & 67.0 & 0 & $100 \% 6$ \\
\hline $\mathbf{S}$. & typhi & & 110.0 & 0 & 100.0 & 83.0 & 0 & 100.0 \\
\hline S. & typhi & & 108.0 & 0 & 100.0 & 59.0 & 0 & 100.0 \\
\hline S. & paratyphi & (A) & 115.0 & 34.4 & 70.2 & 41.0 & 21.0 & 48.8 \\
\hline S. & paratyphi & (B) & 135.5 & 96.0 & 29.3 & 122.5 & 73.5 & 40.0 \\
\hline B. & coli (com & nunis) & 137.0 & 0 & 100.0 & 67.0 & 0 & 100.0 \\
\hline & coli & munior) & 131.0 & 109.5 & 16.5 & 208.0 & 130.5 & 37.0 \\
\hline B. & Pyocyaneus & (教) & 18.0 & 0 & 100.0 & 221.0 & 0 & 100.0 \\
\hline B. & Pyocyaneus & （分） & 35.0 & 0 & 100.0 & 138.0 & 0 & 100.0 \\
\hline B. & Dysenteriae & （駒 B I）. & 70.0 & 14.0 & 81.0 & & & \\
\hline B. & Pneumoniae & F. & 41.0 & 36.0 & 12.0 & 39.5 & 34.0 & 13.0 \\
\hline & Mesen tericus & & 13.0 & 28.5 & $(-120.0)$ & 25.5 & 32.5 & $(-27.0)$ \\
\hline & neumococcus & & 28.0 & 28.0 & 0 & & & \\
\hline & phylococcus & ureus（寺島） & 65.5 & 71.5 & $(-9.0)$ & 35.0 & 36.0 & $(-1.0)$ \\
\hline & aphylococcus & ureus (F.D. A) & 21.1 & 29.6 & $(-24.8)$ & & & \\
\hline
\end{tabular}


馬鈴著菌が加圧により酸素消費肙の増加を 示す点は特に留意すべきで，芴狍を标する㜀 は压に対して抵抗临を有する許りでなく、そ の新陳代謝を却って高める場合があると考へ られる。

\section{3. 菌齢による差異}

細菌呼吸の高压による阻害或は抑制が細菌 の培養時間即ち菌龄によつて異る事は対数增 殖期にある幼若菌は種々の生活機能が元進状 態にあると考へられる事からす予測される所 である、一般淁素消費量は培養時間の短か いすの程多い，而して 16 時間乃至 24 時間の 培養のすのは略一定の酸素消費を示し，48時 間になると相当減少を示す。普通寒天平板培 地飞失々 8 時間， 18 時間， 48 時間及び 72 時 間培羡した菌に就いて $400 \mathrm{~kg} / \mathrm{cm}^{2}$ 乃至 1200 $\mathrm{kg} / \mathrm{cm}^{2}$ の圧を 5 分及び 30 分間加圧した後酸 素消費量を測定した，比較のため，各培视時 間の対照の Qo2 1 とし, 酸素消費星の隇 少を百分比で示すと， $800 \mathrm{~kg} / \mathrm{cm}^{2}$ の圧迄は著 明な差異を認めないが $1200 \mathrm{~kg} / \mathrm{cm}^{2}$ の圧では 加圧 5 分にして幼若菌は著明な呼吸の抑制を

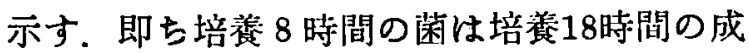
熟菌飞比へ短時間内の加圧で影響を蒙り易い。 之に対し培羡時間の長いるの程影響は少なく， 72 時間培養のものは $800 \mathrm{~kg} / \mathrm{cm}^{2} 30$ 分の加 圧でも殆ど酸素消費の減少を示さない（第 5 図）

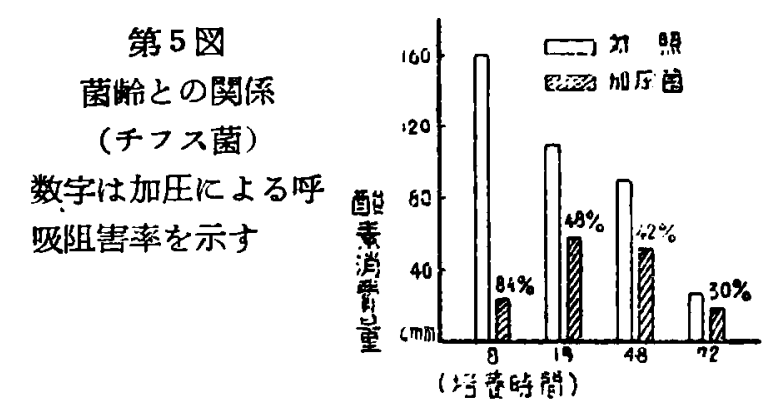

4. 水素イオン濐度及び渗透圧との関係. 加圧の際の条件として菌浮游液の種類によつ ても差異を生ずる事は前篇に於て予測して置 いた，菌浮游液の性状として特に取上げる必 要のあるのは水素イオン濃度及び涪透圧との 関係である。
水素イオン淟度 : チフス菌の生理的食塩 水浮游菌液を一規定の $\mathrm{HCl}$ 及び $\mathrm{NaOH} て ゙$ 種 タ $\mathrm{pH}$ を異にしたものを作り対照と被圧菌に

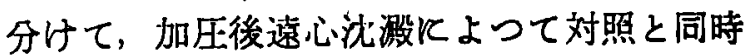
に洗源し，再び $\mathrm{pH} 7.4$ の緩衝液に浮游せし めて基質葡萄糖により酸素消費星を測定した。 単に $\mathrm{pH}$ の異る液に浸すだけでは洗滌して 観察すれば著明な変化は受けないと云つてょ い. 例へば $\mathrm{pH} 4.5$ の夜に30分間浸しても僅 かに10〜20\%の酸素消費の減少を示する過ぎ ない.

対照の $\mathrm{QO}_{2}$ を標準とし高压による呼吸阻 害の程度を百分比で表はすと第 6 図の如くに なる. 即ち (1) $\mathrm{pH}$ が酸性側にある場合高压 による呼吸の㧕制は大である。 $400 \mathrm{~kg} / \mathrm{cm}^{2} 5$ 分の加圧で $30 \%, 30$ 分の加圧で $100 \%$ の阻 害を示している.（2）pH がアルカリ側にある 場合, 阻害は pH 7.4 の場合に比して大差を 認めない，又酸性側では加圧時間が長い程阻 慧されるがアルカリ側では 5 分と30分の加圧 の场合差を認め難い.

济透压：菌浮游液の pII を7.4亿一定し，

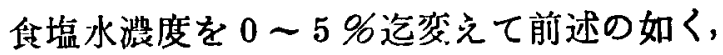
対照と加圧菌液を作り彩透山:の差化よる変化 を追求した結果第 7 図の如き成績を示した。 尚食塩水旅度を変えるだけでは30分以内なら ば洗淮して生理的食塩水飞再浮游せしめれば， そのQ02 とは殆ど影響しない，表示してある のは対照の Q02 を標制とした場合の阻害度 を百分比で比較したものである。（1)低張液即 ち唀压小なる場合には加圧に上る阻害度は 大である. 蒸溜水の埸合が最も大で $400 \mathrm{~kg} / \mathrm{cm}^{2}$ 30分で相当の酸素消背抑制を示している. (2) 等張液 $(0.8596 \mathrm{NaCl})$ 並飞高張液の場合は 阻害度は比輘的小であり，食壏涨度 $5 \%$ の場 合には $0.85 \%$ 場合より更飞阻害は小とな る。即ち高張液になる程高圧に対し保護的に 作用する事が考へられる。

5. 酵素の遊離及び恢復飞就いて。

高圧が菌体に加へられ次で急に除かれた時， 菌体内部にある醇素其の他の物質が菌体外に 遊離するか否か又斯る操作を加へた後に振逜 


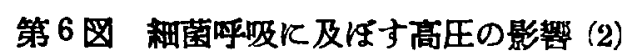
高仕と $\mathrm{pH}$ の成保 (呼吸阻害率).
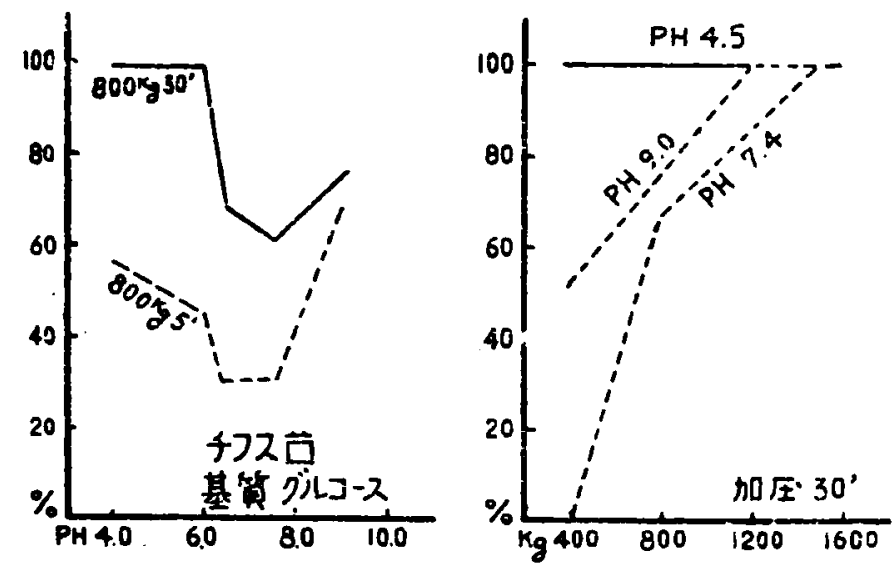

第7因 細菌呼吸に及に槀圧の影響（3： 透压之高压の関俰（呼吸阻害粲）
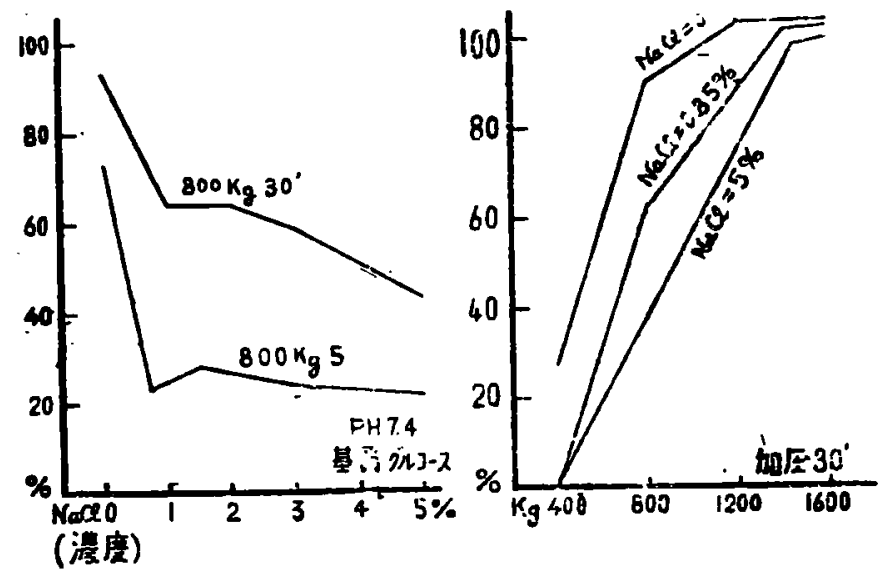

醇素作用の恢復 : 既に前篇固有運動 の観宗の項で一部の菌に加圧によつて 停止していた運動性を恢復する現象を 認めて詳述した。呼吸飞於ても斯る恢 復の現象を認め得るかどうかと云ふ問 題であるが，前掲の第 2 図左飞於て見 られる様に, $1600 \mathrm{~kg} / \mathrm{cm}^{2} 5$ 分の加圧の 場合チフス菌では酸素消費は初め内呼 吸よりも少ないが，2乃至 3 時間の振 凳で次第に消費量は增加する。この現 象は $1200 \mathrm{~kg} / \mathrm{cm}^{\circ} 5$ 分では更に著明であ る。注意すべき事は加压時間が長いと 此の現象は認めないか又は見別け難い。 従つて加压時間の短かい時にのみ呼吸 の恢復といふ現象を観察する事が出来 る.

\section{III 小 括.}

以上の実験を要約すれば次の如くで ある。

（1）細菌の呼吸は高圧によつて抑制 准至阻害を受け或は反対に促進される 場合もある.

(2) 普通桿菌の大部分は $800 \mathrm{~kg} / \mathrm{cm}^{2}$
する場合䤃素の振出が容易になるかといふ疑 点, 更には加圧によつて蒙つた賃害から菌か 恢復するか否かを酳素作用の面から観察し得 るかといふ諸点を本章で取上げて見たい．

醉素の遊離 : 充分洗深したチフス菌の橉 酸楥衙液 $10 \mathrm{mg} / \mathrm{cc}$ 濃度の菌液を作り之に $1600 \mathrm{~kg} / \mathrm{cm}^{2} 30$ 分の加压を行ひ, 10000 r. p. m 10 分の遠心沈澱で完全に菌を沈澱させ上 清を取つて淢萄糖を基質として酸素の消 費を測定した結果，2時閒の振跑で僅か K $3 \mathrm{cmm}$ 程度で, 之は対照と同様の值で ある. 次に同様汒処理した菌液を約 3 時間 $37^{\circ} \mathrm{C}$ の恒温漕中で振酯した後遠沈して得た 上清によつて酸素消費量を検すると，加圧菌 飞於て対照よりる特に酸素消貨が增加する事 実は認め難い，彷つて加圧により䤃素が遊離 し又は遊離し易くなるといふ事は考へられな い.
以上 $1600 \mathrm{~kg} / \mathrm{cm}^{2}$ 迄 30 分間の加圧で大なり

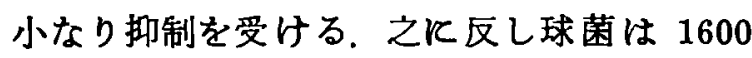
$\mathrm{kg} / \mathrm{cm}^{2}$ の圧では抑制を認めず却つて促進さ れる傾向を有し，芽胞を有する馬鈴薯菌では 促進傾向は著明である。

（3）同一菌種でも株又は型によつて圧に対 する抵抗性を異にする。

（4）菌齢の若いもの程呼吸阻害度は大であ る.

(5) 加圧時の $\mathrm{pH}$ 及び淩透圧飞よつても 異り，アルカリ側よりは酸性側, 又高張液よ りは低張液中飞㸝て加厘の作用は大である。

(6) 加压によつて菌体酵素が遊離し又は振 溜によつて斿離し易くなる事はない。

（7）短時間の加圧の場合には除圧後時間の 経過と共に呼吸を恢復する現象を認めた。 


\section{芽三章 脫水素酵素作用に及ぼす影㛭}

前章飞於て細菌の呼吸醇素（WarburgKeilin 系)の作用が高圧によつて抑制乃至影 響を蒙る事実を種々の実験によつて確めたの であるが，生体の呼吸に参与する重要なる5 一つの醉素系である脱水素酥素も亦影響を受 けるであろう事は推測飞難くない。而して脱 水素酵素作用は Thunberg 法によつて他の 呼吸醉素を除外して観察し得る利点がある。 この方法では脱水素醅素はその特巽基質によ り還元され，且適当飞醉化還元電位を有する 可逆的酸化還元色素で再び酸化される. 茲で はメチレン青が還元されてメチレン白になる 時間（裉色時間）を測定する事によつて酻素 作用を観察した。 、

\section{I 惯 驗方法}

供試菌としてチフス菌（S57 S) 及び葡萄
球菌（寺島株）を用ひ各々18時間培垱のるの

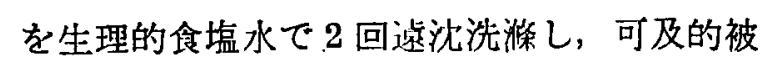
酸化物を除く目的で 60 分間通気を行つた後 $2 \mathrm{mg} / \mathrm{cc}$ の浮游液とした。基質は $1 / 10 \mathrm{Mol}$ 灌度として用ひ，Sörensen とより $1 / 15 \mathrm{Mol}$ 燐酸縓衝液の pH 7.2を用ひて反応を緩衝し た. $\mathrm{H}$ 型 Thunberg 管の主脚に菌液 1.0c.c., 緩衝液 1.0c.c., 副脚飞基質 1.0c.c. 及び Merck 製メチレン青溶液 $1 / 5000 \mathrm{Mol}$ を0.5c.c. 入れ， 対照と加圧菌を一本つう計 2 本を気密に連結 し同時に吸引ポンプで $7 \mathrm{mmHg}$ となる迄吸 引し (5 分間), 次で $38^{\circ} \mathrm{C}$ 恒温榑内飞 2 分間 放置後主脚及び副脚を泿合してょり完全脱色 迄の時間を測定した。

\section{II 霍跧 成 績}

（1）第 2 表に示した如く，チフス第では各 基質を通して $400 \mathrm{~kg} / \mathrm{cm}^{2} 5$ 分加压飞より明ら かとメチレン青脱色時間の延長を認める. 压

第 2 表 高压の脱水素酵素作用に及ぼす影響（メチレン青還元時間）

\begin{tabular}{|c|c|c|c|c|c|c|c|c|}
\hline \multirow[b]{2}{*}{ 于 } & \multirow[b]{2}{*}{ Donater } & \multicolumn{2}{|c|}{$30^{\prime}$} & \multicolumn{4}{|c|}{$\mathbf{5}^{\prime}$} & \multirow{2}{*}{ 対 } \\
\hline & & \multicolumn{2}{|c|}{$1600 \mathrm{~kg}$} & $1600 \mathrm{~kg}$ & $1200 \mathrm{~kg}$ & $800 \mathrm{~kg}$ & $400 \mathrm{~kg}$ & \\
\hline 7 & Glucose & \multicolumn{2}{|c|}{ 120' 㹸色せず } & $41^{\prime} 00^{\prime \prime}$ & $24^{\prime} 00^{\prime \prime}$ & $12^{\prime} 00^{\prime \prime}$ & $13^{\prime} 30^{\prime \prime}$ & $7^{\prime} 30^{\prime \prime}$ \\
\hline z & Aspartic acid & \multicolumn{2}{|c|}{ " } & $54^{\prime} 00^{\prime \prime}$ & $26^{\prime} 30^{\prime \prime}$ & $14^{\prime} 30^{\prime \prime}$ & $12^{\prime} 00^{\prime \prime}$ & $9^{\prime} 00^{\prime \prime}$ \\
\hline \multirow[t]{2}{*}{ 菌 } & Lactic acid & \multicolumn{2}{|c|}{$"$} & $38^{\prime} 00^{\prime \prime}$ & $31^{\prime} 00^{\prime \prime}$ & $12^{\prime} 30^{\prime \prime}$ & $9^{\prime} 30^{\prime \prime}$ & \multirow{2}{*}{$\begin{array}{r}7^{\prime} 00^{\prime \prime} \\
12^{\prime} 30^{\prime \prime}\end{array}$} \\
\hline & Formic acid & \multicolumn{2}{|c|}{$"$} & $64^{\prime} 00^{\prime \prime}$ & $37^{\prime} 30^{\prime \prime}$ & $32^{\prime} 00^{\prime \prime}$ & $13^{\prime} 00^{\prime \prime}$ & \\
\hline \multirow[b]{2}{*}{ 溨 } & & \multicolumn{2}{|c|}{$30^{\prime}$} & \multicolumn{4}{|c|}{$5^{\prime}$} & \multirow{2}{*}{ 対 } \\
\hline & Donater & $1600 \mathrm{~kg}$ & $400 \mathrm{~kg}$ & $1600 \mathrm{~kg}$ & $1200 \mathrm{~kg}$ & $800 \mathrm{~kg}$ & $400 \mathrm{~kg}$ & \\
\hline \multirow[b]{2}{*}{ 球 } & Glucose & $24^{\prime} 00^{\prime \prime}$ & $15^{\prime} 00^{\prime \prime}$ & $18^{\prime} 30^{\prime \prime}$ & $21^{\prime} 00^{\prime \prime}$ & $20^{\prime} 00^{\prime \prime}$ & $19^{\prime} 00^{\prime \prime}$ & $19^{\prime} 30^{\prime \prime}$ \\
\hline & Maltose & $30^{\prime} 00^{\prime \prime}$ & $11^{\prime} 00^{\prime \prime}$ & $11^{\prime} 30^{\prime \prime}$ & $10^{\prime} 00^{\prime \prime}$ & $12^{\prime} 00^{\prime \prime}$ & $11^{\prime} 00^{\prime \prime}$ & $11^{\prime} \cdot 30^{\prime \prime}$ \\
\hline \multirow[t]{2}{*}{ 菌 } & Lactic acid & $17^{\prime} 00^{\prime \prime}$ & $9^{\prime} 00^{\prime \prime}$ & $8^{\prime} 30^{\prime \prime}$ & $7^{\prime} 30^{\prime \prime}$ & $8^{\prime} 00^{\prime \prime}$ & $7^{\prime} 30^{\prime \prime}$ & $8^{\prime} 00^{\prime \prime}$ \\
\hline & Formic acid & $38^{\prime} 00^{\prime \prime}$ & $9^{\prime} 30^{\prime \prime}$ & $7^{\prime} 30^{\prime \prime}$ & $8^{\prime} 30^{\prime \prime}$ & $7^{\prime} 00^{\prime \prime}$ & $9^{\prime} 00^{\prime \prime}$ & $9^{\prime} 30^{\prime \prime}$ \\
\hline
\end{tabular}

が高くなると更に著明に延長する。 1600 $\mathrm{kg} / \mathrm{cm}^{2} 30$ 分の加圧では 120 分後です完全に は脱色しない。

（2）短時間の加圧又は比輅的低い圧の場合 悦色の開始迄が遅延するが，開始より完了 迄の時間は対照と殆ど変らない。之はメチレ ン青の段階的稀釈液を対照にとり比較する事 によつて確め得た。

（3）葡萄状球菌では $1600 \mathrm{~kg} / \mathrm{cm}^{2} 30$ 分加圧
の場合のみ脱色時間の延辰を認めるが 5 分の 加压では変化ないか又は僅かに促進される場 合があり，基質によつて多少の差異を認めた。 例へば蟻酸は促進傾向が明らかであるが，他 の基質は不定である.

\section{III 小 括}

以上の実験を要約すると, (1) H 型 Thunberg 管を用ひ対照と加圧菌液の二本を連結し，同 
時に吸引して真空状態を等しくする事によつ て実験誤差を僅微のすのとする事が出来た，

（2）脱水素酥素作用の抑制乃至阻害は 400 $\mathrm{kg} / \mathrm{cm}^{2} 5$ 分の加压より認める事が出来た. 之は前章呼吸の場合飞比し, 相当の差異があ るが，酵素の抵抗性といふよりはむしろ実験 方法の差飞基くと解する方が穻当であろ5. 此の点飞就いては更に後章で述へる事にする. (3) 萠匋球菌は低い压又は短時間の加圧では むしろ促進の傾向を認めるが $1600 \mathrm{~kg} / \mathrm{cm}^{2} 30$ 分の加圧になると脱水素䤃素作用は㧕制を受 ける.

\section{第四革 カラターぜ作用に及ぱす影管}

好気性生物飞於ては分子状酸素を水素受容 体として働く脱水素酵素の作用により過酸化 水素が生成されるが，カタラーゼの生理的意 義はこの $\mathrm{H}_{2} \Upsilon_{2}$ を分解し酵素と水にな寸事に あると考へられていたが，Keilin 等の研究に よるとカタラーゼは脱水素醅素の作用により 生じた $\mathrm{H}_{2} \mathrm{O}_{2}$ に㗢き，恰すへルオキンターゼ の如く，他の物質の酸化を促進する作用を有 する事が判つた． 即ちカタラーゼす又生体酸 化に一役をかつているのである。従つて細菌 醉素作用の一つとしてカタラーゼ作用に及ほ す高圧の影響を追求する事によつて本篇に於 て企図する所を更に補足したい，細㡀カタラ 一ゼの研究は外国の文献を待つまでるなく, 本邦に於て多数の業績が战されているので其 等を参考にしつ〉，細藏カタラーゼの 外家兔赤血球カタラーゼ及び牛肝抽出 カタラーゼの作用を比較しながら高圧 の作用を検討した。

\section{I 霍驗方法}

カタラーゼ作用測定 : 藤田秋治氏の 方法に従ひ，細菌カタラーゼが過酸化 水素水を分解して発生する酸素量を Warburg の検压法により測定した. 容器内各容量は次の通りである。

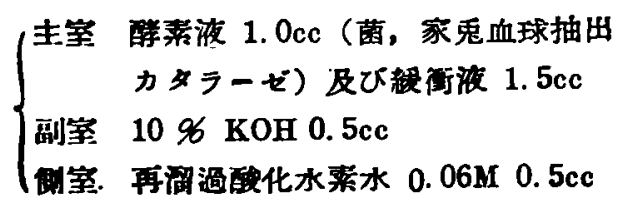

䌅衝液組成

$\left\{\begin{array}{llr}0.154 \mathrm{M} & \mathrm{NaCl} & 950 \mathrm{cc} \\ 0.154 \mathrm{M} & \mathrm{NaH}_{2} \mathrm{PO}_{4} & 7.5 \mathrm{cc} \\ 0.11 \mathrm{M} & \mathrm{Na} . \mathrm{HPO} & 42.5 \mathrm{cc} \\ 0.154 \mathrm{M} & \mathrm{NaHCO} & 2.0 \mathrm{cc}\end{array}\right.$

測定温度は $37.5^{\circ} \mathrm{C}$ 振䒸回数 $120 /$ 分 測定 時間は 30 分間である。

家鬼赤血球浮游液：家兔心血 5cc を採取し， 生理的食塭水で 3 回遠沈洗源し, 沈澱の最上 層の白色不透明の薄層 (白血球)をピペット とより除去し赫血球のみを得て適宜稀釈す る.

抽出精製カタラーせ：牛肝缄を磨厒した

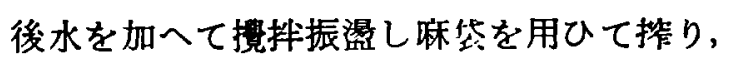
汁液を滤過した後にアルコホルによつて除蛋 白を施し，更にアルコホル，及びクロロホル ムを加へて残存せる蛋白質とへモグロピンを 除去す。斯くして得た粗製力タラーゼ液より 中性燐酸カルンウムによつて吸着物を除き次 で $1969 \mathrm{Na}_{2} \mathrm{HPC}_{4}$ 水溶液に入れて溶離した 液を低温にして透析し精製カタラーゼ液を作 る.

\section{II 霓 驗成續}

\section{1. 細藏カタラーゼ}

チフス䉒では $1600 \mathrm{~kg} / \mathrm{cm}^{2} 30$ 分の加庄によ り対照に比べて約 $30 \%$ の酸素発生量の減少を 認め大.（第 8 网）併し $1200 \mathrm{~kg} / \mathrm{cm}^{2}$ 以下の

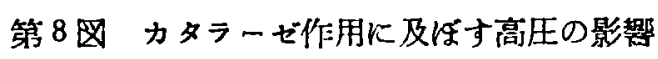
酸素発生量の比較

A. 牛肝抽出カタラーゼ及家象赤血球カタラーゼ

B. 細菌カタラーゼ
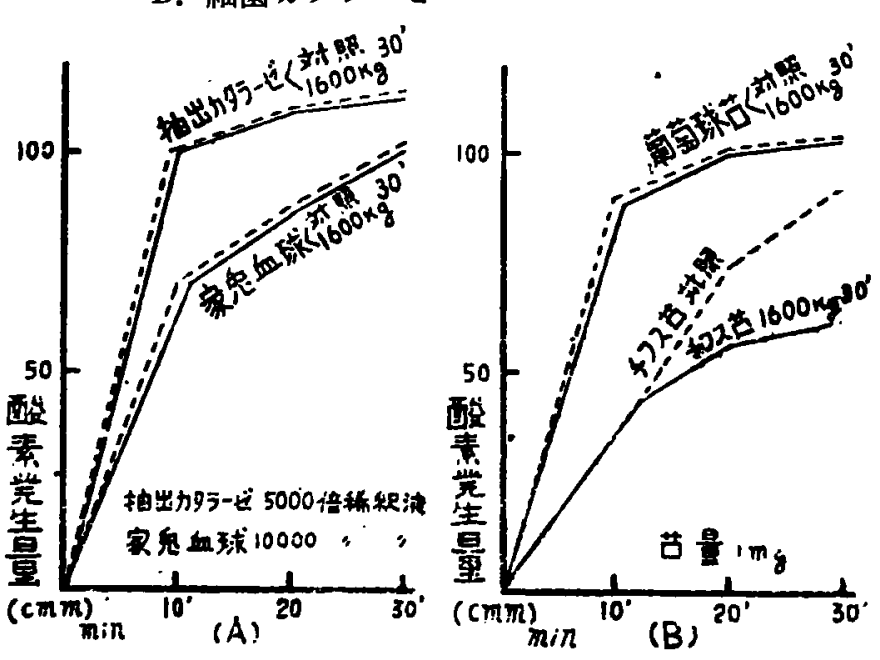
圧では殆ど影響を認めない，他の桿菌でも同

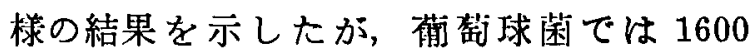
$\mathrm{kg} / \mathrm{cm}^{2} 30$ 分の加圧によつてカタラーゼ作用 に全く影響しない。

․ 家鬼亦血球カタラーセ

$1600 \mathrm{~kg} / \mathrm{cm}^{2} 30$ 分の加圧によつて子血球力 タラーゼによる酸素発生量は対照と全く変ら ない.（第 8 図）。

3. 牛肝抽出力タラーゼ.

$1600 \mathrm{~kg} / \mathrm{cm}^{2} 30$ 分の加圧によつて何等の変 化を認めなかつた（第 8 図）

\section{III 小 括}

以上を要䄪すると Warburg 検生法によつ て細菌，家鬼赤岒球並飞抽出精彆カタラーゼ

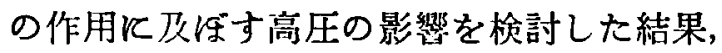
細菌カタラーゼのうちチフス菌等一部桿菌の カタラーゼ作用が抑制又は阻害されるのを涊 めた以外飞は，球菌，家兔赤血球，亚飞牛肝 抽出カタラーゼのいづれも全く影響を蒙らな いことを確めた。 之注よりカラーゼ作用が 細菌の形状や絉胞膜の透過性习は菌の生活機 能の障碍の程度と密接な関連を有する事を予 測し得る，又単離された酻素そのものは此の 程度の圧では変化を受けないと考へられる。

\section{第五章 考按}

酔素作用に対する高圧の影響飞就いては生 理学の領域に於て若干の研究が為されている 外, 細菌学領域では文献的に極めて僅かの報 告があるのみである。: 即ち E. Büchner は 1897亿醉母飞压を加へてチマーぜを分離して いるが H. Büchner は之を一般細菌に応用し て失敗している. Certes（1889）は300〜500 気圧の下では細菌の㦄敗作用及び酵母の酸醉 作用のいづれす阻害しないと報告した。 Chlopin 及び Tamman (1904) とよれば 3000 $\mathrm{kg} / \mathrm{cm}^{2}$ の圧を 96 時間に互り加圧する事によ つて醅母の酸䤏作用を阻害する事を報じてい る. 更に近年に至り米国の Johnson一派の発 光菌に関する一連の研究によ゚つて海底に棲む 或種の菌の Metabolism が相当の圧力に抵抗
を有するのみでなく，適度の圧の場合には却 つて促僬される傾后のある事を発見してい る. 其の外, Johnson, Kautsmann, Genser 等(1948) 沈るる invertase, Fraser, Johnson （1951）によるトリプンンの作用に及ぼす高 压の影響化就いての研究があるが之等は細菌 学領域を逸脱するので茲には述へない，本篇 に於て述へた細菌の呼吸醉素, 脱水素醉素, カタラーゼ作用等飞就いて高压の作用を研究 した文献は私の調へたた範囲では見当らない。 以下実験成績に関して考察を加へたい。

チフス菌は $800 \mathrm{~kg} / \mathrm{cm}^{2} 30$ 分の加圧より呼 吸の阻害が現はれるが之は比濁法によつてチ フス菌增殖曲線の lag phase の延長を認める のと轧を一にしている，亦運動を示す菌が減 るのも此の程度の加圧からである. 即ち此の 程度の加压により運動を停止し，呼吸を阻害 され且, 增殖を荤砒させられる一部の菌が存 在する事を示している，呼吸の抑制乃至阻害 は压の高い程，又加座時間の長い程大とな る，又基質によつても同一奏験飞於て酸素消 費量の消!、往を生ずる事は與味ある点で ある. Johnson 等は高圧の作用として蛋白の 変性特に分子の容積の変化を強調している. 即ち高压により蛋白分子は球状の配列から線 状の配列に変觉られ，分子全体の容積が変化 すると述べている．斯る変化が基質との接触 を容易に或は困難にし，従つて醉素作用に影 響を及ほすすのと涄へられる，基質によつて 多少の差があるのは，例へば，蔽䓒料とアス パラギン酸とではその分子量が異なる上, 棈 造を異にしているから醉素との接触と於ても 差異る生じてよいわけである。球䔉に於て概 权高圧の作用が少ないか又は促進的偟き， 桿菌に於て阻害的に衔くのは形態上の差巽飞 基くと考へられるが，同一の菌種でも株を異 にし，又は型を異にすると抵抗性が変るのは 恐らく菌体表面構造上の差異によるすのと考 へられる，梁胞を有する菌が高压に対し極め て強い抵抗を示す事は前篇に於てわ述へたが， 呼吸に於ては $1600 \mathrm{~kg} / \mathrm{cm}^{2}$ 程度の圧では却つ て促進的に作用するのは，その細胞膜に対し 
て或種の変化を与へ，それが酥素作用を旺に するすのと洘へる事が出来るが詳紐は尚不明 である。

加圧時の Medium の $\mathrm{pH}$ 及び洛透圧が圧 による菌の傷害に影響を及ぼす因子となる事 実も呼吸の測定によつて確認された。即ち， $\mathrm{pH}$ ではアルカリ側に於て, 亦唀唀では高 張液飞於て夫っ酸性側及び低張液に於けるよ りる圧汶対する抵抗が強い，従つて相当深い 海底にも菌が棲息し得るのも斯る点より首肯 される。

次飞本害験飞於て使用した程度の hydrostatatic pressure では酵素が直接菌体外飞圧 出されたり, 又は振盪によつて振出し易くな るといふ事実は認められないがッ゙は蔺体が完 全に破壞される程には甚大な变化を影らない と解して良いと思ふ。

呼吸に於ても恢復の現象を一部に涊めたが 之は圧の高さと加圧の時間に略比例し, 固有 運動に於て観察された運動麻痻と相通ずるも のがあり麻㽻が酵装作用にも及ぶ事を推測さ せる。

Claude, Zobell 等㤝高圧か酸化還元電位V ○変化を及ぼす可能性を予測しているが, Thunberg 法によるメチレン青還て時間の测 定による脱水索醉素反応の実験に片てて，加在 とよりチフス藏の色委濖元時間の遅延を認め た事は”を望皆するるのである． $400 \mathrm{~kg} / \mathrm{cm}^{2}$ 5 分の加圧で既に色素選元時間の遅延する点 は呼吸酵素の場合よりる漼かに低い压で早く も影響を蒙るかの如くであるが，注意すべき 事以脱色開始迄が遲れるのみで脱色開始より 完了迄の時間は対照と変らない事である。 之 は基質と醉素との接触が円滑に行はれず酵清 が基質によつて充少飽和される迄に時間を要 するのではなからうか，而して酻素作用が一 且始まると反忘は遅兴なく進むものと考へら れる．基質と酵素の接触が円滑充分でないと いら事は菌体表面構造の変化乃至は蛋白質の Denaturation の可能性を考へさせるるので ある. 脱水素酵素と呼吸酵素の作用汇高圧の 影響の差異がある様に見えるのは前者が実験
操作容易なためと後者よりる加压後比洓的短 時間内反反心を調へる事が山来るために低い 压によつて軽度の傷害を管つた菌を恢復する 前に観察し得るからである5，從つて呼吸に 於ても $400 \mathrm{~kg} / \mathrm{cm}^{2}$ 程度の压飞よつて奏験方 法上証明し得ないが恐らく多少の影響を受け るすのと考へる事が出来る.

カタラーゼ作用に関する契験も同様に菌体 表面に於ける或種の変化を予想させる. 何故 ならぼ単離した牛所抽出カタラーゼの作用が 何等の変化る蒙らないのに, 菌のカタラーゼ 作用は可成り低減している. 之は酵素として のカタラーゼの加压による破壊では無く, 菌 の表面樥造の変化によつてカタラーゼと過酸 化水素の接触が覀くなつた事, 或はカタラー ゼの作用を充分に働かせない何等かの変化が 莯体に生じたと解する事が可能である。

\section{第六章 結論}

細荣の䣼素作用に及ぼす高圧の影響をた々

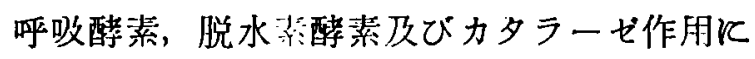
就いて追求し次の結果を得た。

1) 細菌の呼吸は, 普通桿菌の大部分のる のは $800 \mathrm{~kg} / \mathrm{cm}^{2}$ 以上 $1600 \mathrm{~kg} / \mathrm{cm}^{2}$ 迄の圧で 30 分の玔により完企に或は一部阻害を蒙る。

己に反し球菌は何等の㧕制を認めず却つて多 少の促倠を見る，芽胞菌は促進傾向著明であ

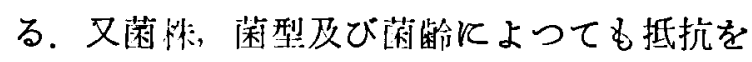
異に与る外，加圧時の Medium の $\mathrm{pH}$ 及び 济透压等の因子も無視出来ない。一部に呼吸 の恢復を認めたが，加压によつて特に酻素が 遊離し易くなる㭋な現缐は認められない。

2）脱水素酵素作用はチフス菌では 400 $\mathrm{kg} / \mathrm{cm}^{2} 5$ 分の加圧により著明な影響を蒙る。 即ち色溸愣元時間の遲延を認める。葡萄球菌 では $1600 \mathrm{~kg} / \mathrm{cm}^{2} 30$ 分の加压により始めて遅 延を認めるが低い压では遅延を認めないか又 は促進的である。

3）カタラーゼ作用では桿菌は $1600 \mathrm{~kg} / \mathrm{cm}^{2}$ 30分の加圧で酸素発生量の減少を示すが之は 呼吸の場合よりも高い圧でなければ認められ ない. 球菌, 家兔赤血球, 及び牛肝抽出精製 
カタラーゼでは此の程度の圧では影響を認め ない.

要すると醇菜作用の阻害は恐らく，醉苝と 基質の接触が円滑に行はれないためで”は細
菌の細胞膜の移過性の異常, 或は表面構造の 変化が主なる原因であると考へられる，此の 点に就いては第三篇に於て明らかてしたい. 